UDC

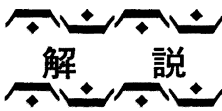

\title{
金属資源シリーズーニッケルー
}

野原 隆 昭*

\section{Metallic Resources Series -Nickel-}

\section{Takaaki NoHARA}

始 め に

ニッケル，この強く，硬く，柔軟性富み，耐熱・耐 食性に優れ，ほとんどあらゆる他の金属と合金をつくつ て優れた特性を創り出す “金属の塩”之呼ばれる金属 が，ニューカレドニアで始めて本格生産されてちょうど 100 年になる。皇れ以来，第一次世界大戦を契機とした 軍需, 大戦後の INCO 社を中心とした民需の開拓, そ して第二次大戦中の兵器の近代化, 電気通信機器の急速 な発展による飛躍的な需要增（当時の生産量 16.4 万 $\mathrm{t}$ 一第一次大戦中の約 3 倍増一), その後の航空機, 原子力, 石油化学などの分野での需要桩大と, 多少の紂余曲折は あつたが、ニッケルの需要はほほぼ順調に伸びてきたとい 兄よう. 生産もこれに呼応して量的にも地域的にも拡大 されてきた，鉱石べースでみると 1950 年当時, ニッケ ルはカナダ, ニューカレドニア及びり連の 3 カ国で計約 18.4 万 $\mathrm{t} /$ 年生産されていたにすぎず，取り分け自由世 界の総生産の $95 \%$ はカナダーオンタリオ地区で生産され ていたが，今日では世界の約 20 力国で約 75 万 $\mathrm{t} /$ 年生 産されるようになつている。また， 3 大生産者である INCO，Falconbridge 及び Le Nickel の自由世界に おけるマーケットシェアは 1965 年当時で併せて 85\% とほぼ寡占状態であつたが, 新規参入の生産者が相次ぎ, 現在では約 $50 \%$ に低下している.

一方，我が国に目を転じると，資源的には $100 \%$ 輸入 国であるが，時代の要請からいわゆる国産製錬業者は現 在 7 社を数兄, 年間約 10 万 $\mathrm{t}$ を生産している. 需要む

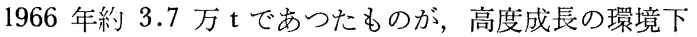
年々着実に増加し，1973 年には約 12 万 $\mathrm{t}$ に達したが, 低成長時代に入つてその後は 8 万 $\mathrm{t}$ から 14 万 $\mathrm{t}$ の間を 一進一退している.

\section{1. 現状}

\section{$1 \cdot 1$ 鉱石の種類とその製品}

ニッケルは金や銀のように純金属の形では自然界に存
在せず，硫黄，酸素，ケイ素と結びついた形の硫化鉱や酸 化鉱として産出される．資源としてのニッケル源は, 硫化鉱，酸化鉱及びマンガンノジュール (Manganese Nodule) に大別される（マンガンノジュールについて は後述).この内, 現在の商業ベースでのニッケル源は硫 化鉱と酸化鉱である。おおざつぱにいつて酸化鉱は北緯 40 度, 南緯 20 度より低緯度地域に存在し, 主に二ュ一 カレドニア，インドネシア，フィリピソキュュー゙, オ 一ストラリア北部などで産出される，一方，硫化鉱は酸 化鉱に比較し高緯度地域に存在し，主にカナダ，オース トラリア南部, ソ連などで産出される。

硫化鉱の代表としては, Pentlandite $\left[(\mathrm{Ni}, \mathrm{Fe})_{9} \mathrm{~S}_{8}\right]$ が あり，酸化鉱の代表としては Garnierite $\left[(\mathrm{Ni}, \mathrm{Mg})_{6}\right.$ $\left.\mathrm{Si}_{4} \mathrm{O}_{10}(\mathrm{OH})_{8}\right]$ 及び Nickeliferous Limonite-通称ラテラ イト (Laterite) $-\left[(\mathrm{Fe}, \mathrm{Ni}) \mathrm{O}(\mathrm{OH}) \cdot \mathrm{nH}_{2} \mathrm{O}\right]$ がある.

現在ニッケルの約 $60 \%$ は硫化鉱から，残り約 $40 \%$ は酸化鉱 (Laterite Ore/Garnierite Ore) から生産され ているが，全世界の陸上ニッケル埋蔵量の内約 $80 \%$ が 酸化鉱であると言われていることを考兄ると，将来は酸 化鉱からの生産が主流を占めることとなるう。

また，現在確認されている陸上資源としてのニッケル

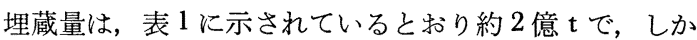
もこの内約半分がインドネシア及びニューカレドニアに 集中しており，周辺のフィリピン及びオーストラリアを 含めると約 $60 \%$ の集中度となる。

表 2 は鉱石の種類とそれからの中間製品/最終製品及 び最終製品の主要生産者の関連を表にまとめたものであ る.

ニッケル製品は従来から Class I 及び Class II に分類さ れている・すなわち Class I とは一般的にニッケルが高品 位であり，用途に汎用性がある製品でニッケルブリケッ 卜, 電解ニッケル, ニッケルペレット等を指す. Class II とは Class I に比較し,ニッケルが低品位であり用途が限 定される製品で，フェロニッケル，酸化ニッケル $(\mathrm{Ni}-$ ckel Oxide Sinter) 等を指す。また，最近になり用途

昭和 56 年 1 月 21 日受付 (Received Jan. 21，1981) （依頼解説）

* 三井物産(株)非鉄金属第 2 部 (2nd Non-Ferrous Metals Div., Mitsui \& Co., Ltd., 1-2-1 Otemachi Chiyoda-ku 100) 
による分類法も用いられるよらになつた.すなわち Class A/Class B /Class C の 3 分類法である. Class A とは めつき用ニッケル, Class B とは溶解用ニッケル（ペレッ

表 1 ニッケルの確認埋蔵量4)

\begin{tabular}{|c|c|c|}
\hline & $\begin{array}{l}\text { 埋蔵 量 } \\
(1000 \mathrm{t})\end{array}$ & $\begin{array}{l}\text { 全世界に対す } \\
\text { る割合 }(\%) \\
\end{array}$ \\
\hline $\begin{array}{l}\text { (北米) } \\
\text { アメリカ } \\
\text { カナ ダ }\end{array}$ & $\begin{array}{l}13700 \\
19200\end{array}$ & $\begin{array}{l}6.6 \% \\
9.3 \%\end{array}$ \\
\hline 北米小計 & 32900 & $15.9 \%$ \\
\hline 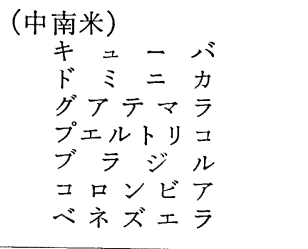 & $\begin{array}{r}16000 \\
1100 \\
1100 \\
800 \\
3700 \\
1400 \\
600\end{array}$ & $\begin{array}{l}7.7 \% \\
0.5 \% \\
0.5 \% \\
0.4 \% \\
1.8 \% \\
0.7 \% \\
0.3 \%\end{array}$ \\
\hline 中南米小計 & 24700 & $11.9 \%$ \\
\hline $\begin{array}{c}\text { (東南アジア/豪州) } \\
\text { オーストラリア } \\
\text { インドネシア } \\
\text { ニューカレドニア } \\
\text { フィリピン }\end{array}$ & $\begin{array}{r}8000 \\
57000 \\
41700 \\
14800\end{array}$ & $\begin{array}{r}3.9 \% \\
27.6 \% \\
20.2 \% \\
7.2 \%\end{array}$ \\
\hline 東南アジア/豪州小計 & 121500 & $58 \cdot 9 \%$ \\
\hline 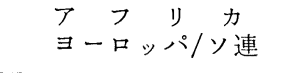 & $\begin{array}{r}8200 \\
19300\end{array}$ & $\begin{array}{l}4.0 \% \\
9.3 \%\end{array}$ \\
\hline 世界合計 & 206600 & $100.0 \%$ \\
\hline
\end{tabular}

ト, ブリケット，溶解用電解ニッケル等), Class C とは チャージ用ニッケル(フェロニッケル，酸化ニッケル等） を各々指す。ニッケル全体の使用量に占める大体の割合 は ClassA が 15\%, Class B が 40\%, ClassC が 45\% である1).

主要ニッケル製品の概略は下記のとおり.

。電解ニッケル：最も古くからある最もポピュラーな 製品であり，電気分解の工程を経て製造される. ニッケル品位は $99.9 \%$ 以上であり, 鉄鋼・高二 ッケル合金・めつき等あらゆる分野で消費されて いる.

○フェロニッケル：主に鉄鋼分野で消費されるフェロ ニッケルは，原料となる鉱石中の $\mathrm{Fe} / \mathrm{Ni}$ 比及び 製錬方法によりニッケル品位は異なるが，一般的 にニッケル品位は $20 \sim 50 \%, \mathrm{C}, \mathrm{Cr}, \mathrm{Si}$ 等の不純 物が $5 \sim 10 \%$ ，残りは $\mathrm{Fe}$ である。

。酸化ニッケル：フェロニッケルと同様, 主に鉄鋼分 野で消費される酸化ニッケルは, 中間原料である ニッケルマット中のニッケル品位により異なる が，一般的にニッケル品位は $75 \%$ ないし $90 \%$ ， 残りは酸素である.

\section{$1 \cdot 2$ 自由世界のニッケル生産者と日本のニッケル製錬 業者}

表 4 は自由世界のニッケル生産者名, 工場所在地, 主 要製品及び生産能力を表にまとめたものである。これら ニッケル生産者の内, INCO (カナダ), Falconbridge (カナダ) 及び Societe Metallurgical le Nickel一通称 SLN-(フランス) は世界の 3 大生産者と言われ，自由世

表 2 鉱石の種類・最終製品および主要生産者の関連図

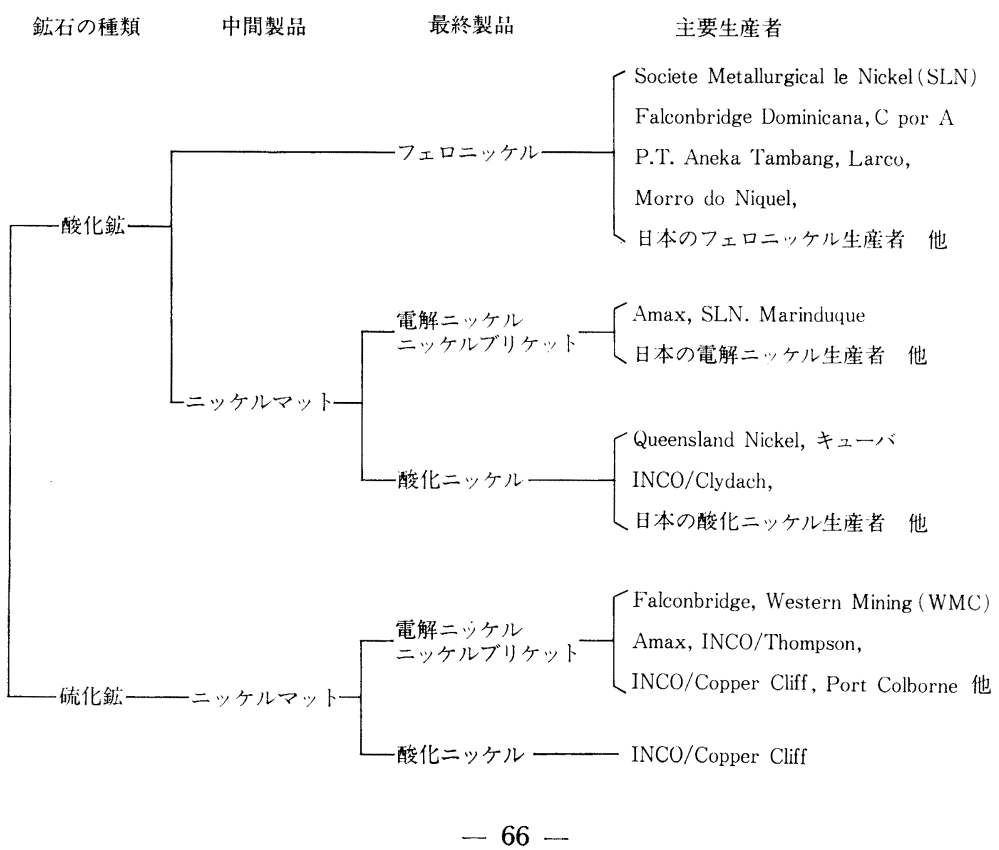


表 3 主要なニッケルの形態4

\begin{tabular}{|c|c|c|c|c|c|c|c|c|c|}
\hline & & & & 化 学 成 & $(\%)$ & & & & \\
\hline & $\mathrm{Ni}$ & C & $\mathrm{Cu}$ & $\mathrm{Fe}$ & $\mathrm{S}$ & Co & $\mathrm{O}$ & $\mathrm{Si}$ & $\mathrm{Cr}$ \\
\hline 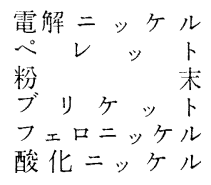 & $\begin{array}{c}>99.9 \\
>99.97 \\
99.74 \\
99.9 \\
20-50^{(1)} \\
76.0\end{array}$ & $\begin{array}{c}0.01 \\
<0.01 \\
<0.1 \\
0.01 \\
1.5-1.8 \\
-\end{array}$ & $\begin{array}{l}0.005 \\
0.0001 \\
\overline{-} \\
0.001 \\
\overline{-75}\end{array}$ & $\begin{array}{l}0.002 \\
0.0015 \\
<0.01 \\
0.002 \\
\text { Balance } \\
0.3\end{array}$ & $\begin{array}{l}0.001 \\
0.0003 \\
<0.001 \\
0.0035 \\
<0.3 \\
0.006\end{array}$ & $\begin{array}{l}0 . \overline{0}=005 \\
0 . \overline{03} \\
1 . \overline{-}^{(1)}\end{array}$ & $\begin{array}{c}\overline{\bar{E}} \\
<\overline{0.15} \\
\overline{-} \\
\text { Balance }\end{array}$ & $\begin{array}{l}- \\
\overline{-} \\
\overline{1.8-4} \\
-\end{array}$ & $\begin{array}{c}- \\
- \\
1.2-1.8 \\
-\end{array}$ \\
\hline
\end{tabular}

(1) $1-2 \%$ の Co が Ni 中に含まれている.

表 4 自由世界のニッケル生産者の設備能力2)

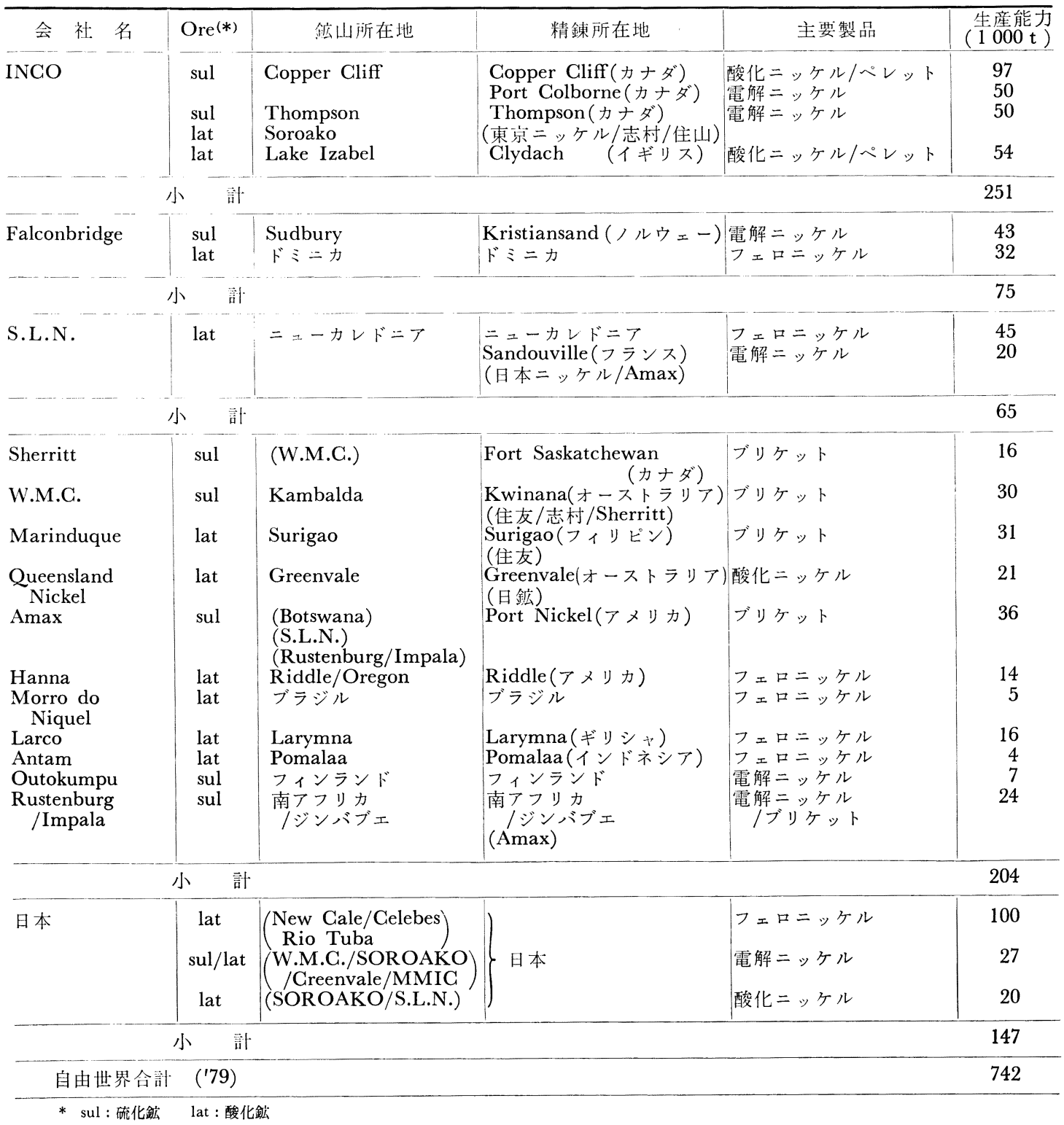


表 5 国内製錬業者の設備能力2)

1. フェロニッケル

\begin{tabular}{|c|c|c|c|c|c|}
\hline & $\begin{array}{l}\text { 生産能力 } \\
\text { ( } \mathrm{t} / \text { 年) }\end{array}$ & \multicolumn{2}{|l|}{ 設 } & \multicolumn{2}{|c|}{ 備 $(\mathrm{t} /$ 月 $)$} \\
\hline 住友金属鉱山[日向］ & 26400 & エルケム炉（4 基） & \multicolumn{3}{|c|}{$\begin{array}{c}15000 \mathrm{k} \mathrm{V} \mathrm{A} \times 2[1 \sim 2 \text { 号炉 }](350 \times 2) \\
25000 \mathrm{k} \mathrm{V} \mathrm{A} \times 2[3,6 \text { 号炉 }](750 \times 2) \\
\text { 月間計 } 2200\end{array}$} \\
\hline 大平洋金属 [八 戸] & 25200 & エルケム炉（3 基） & 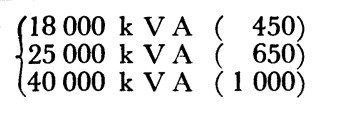 & 月間計 & 2100 \\
\hline 志 村 化 工[伊 達] & 18600 & \multicolumn{2}{|c|}{ 電炉（3 基） $\quad\left\{\begin{array}{l}16000 \mathrm{k} \mathrm{V} \mathrm{A} \quad(350) \\
8150 \mathrm{k} \text { V A } \times 2(600 \times 2)\end{array}\right.$} & 月間計 & 1550 \\
\hline $\begin{array}{r}\text { 日本治金工業[大江山] } \\
{[\text { 昭 }} \\
\text { 電] } \\
\text { 治金哔) }\end{array}$ & $\begin{array}{r}12000 \\
4200 \\
16200\end{array}$ & \multicolumn{2}{|c|}{ 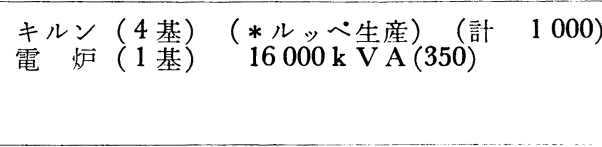 } & 月間計 & 1350 \\
\hline 日 本 鉱 業[佐賀関] & 13800 & $\begin{array}{l}\text { エルケム炉（1 基） } \\
\text { 溶 鉱 炉 }\end{array}$ & $27000 \mathrm{k}$ V A $(800)$ & 月間計 & 1150 \\
\hline フェロニッケル計 & 100200 & & & & \\
\hline
\end{tabular}

2. 酸化ニッケル

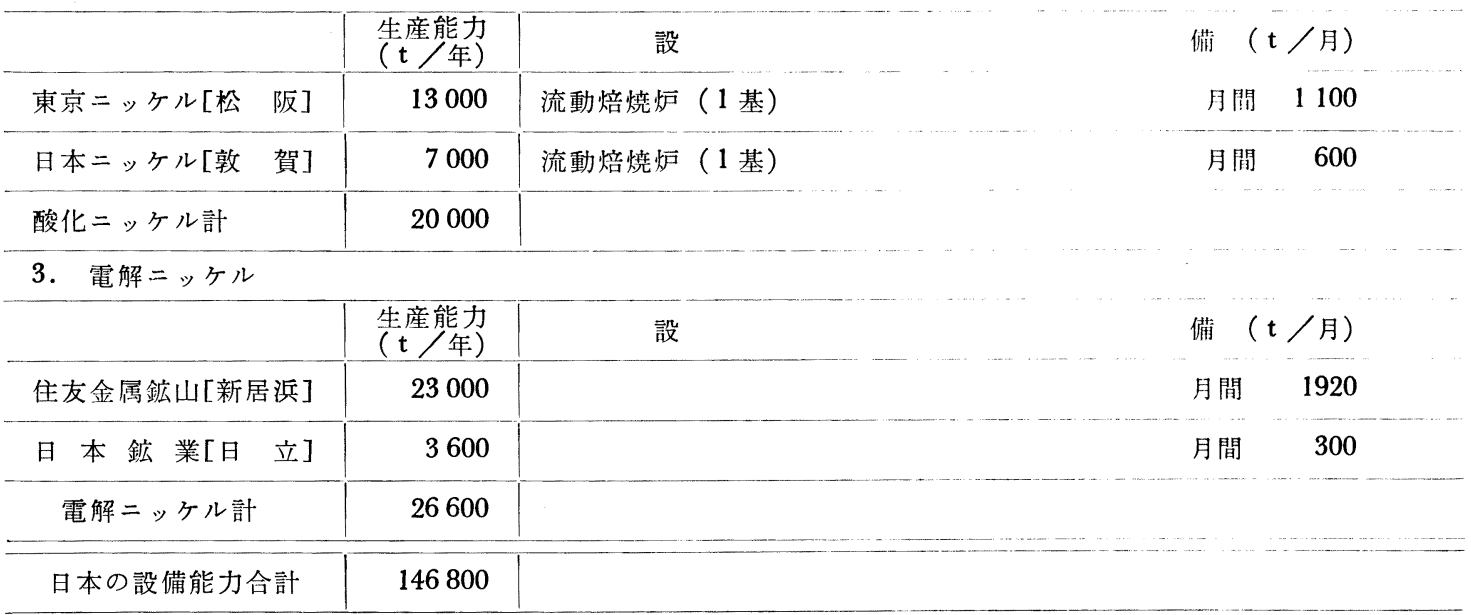

界の生産能力の $50 \%$ 強を保有している. また, 日本の ニッケル製鍊業者は自由世界の生産能力の約 $20 \%$ を保 有している.

また，製品別に見ると，電解ニッケル及びブリケット の生産能力は 42.9 万 t $(58 \%)$, フェロニッケルは 21.6 万 $\mathrm{t}(29 \%)$, 酸化ニッケルは 9.7 万 $\mathrm{t}(13 \%)$ である.

表 5 は日本のニッケル製錬業者名及び生産能力を表に まとめたものである. 日本のニッケル生産能力 14.7 万 $\mathrm{t}$ の内, フェロニッケルは 10 万 t $(67 \%)$, 酸化二ッヶ ルは 2 万 $\mathrm{t}(14 \%)$, 電解ニッケルは 2.7 万 $\mathrm{t}(19 \%)$ で あり, 自由世界の生産能力の内訳と比較してフェロニッ ケルの生産能力が相対的に多いことがわかる. これは次
（用途別/地域別消費内訳）に述べられているように，日 本のニッケル産業が需要先として鉄鋼分野, 特にステン レス鋼分野に強く依存していることを物語つている.

\section{3 用途別/地域別消费内訳}

INCO によれば，最近の自由世界全体でのニッケル消 費の用途別内訳は約 $45 \%$ がステンレス鋼分野，約 $10 \%$ が合金鋼分野，約 $20 \%$ が高ニッケル合金やキュブロニ ッケルのような非鉄合金分野, 約 $10 \%$ が鋳鍛鋼分野, 約 $10 \%$ がめつき分野となつている, 残りの $5 \%$ は触媒 や粉末治金，含ニッケルバッテリーなど新規でかつ高度 な技術分野で消費されている ${ }^{1)}$ ところがこの用途別消 費内訳を 2 大消費国であるアメリカと日本で比較してみ 


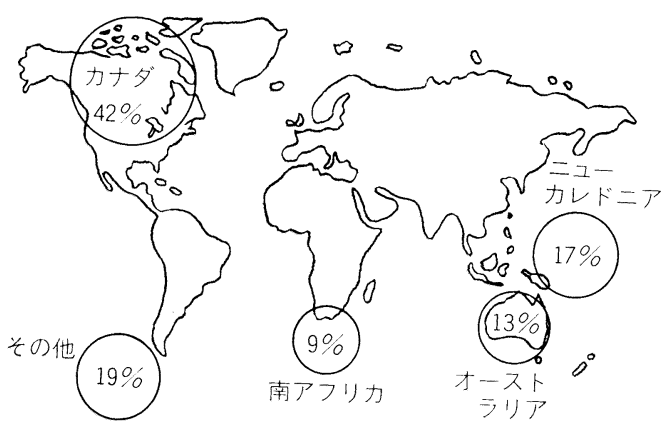

図 1 自由世界の地域別ニッケル生産

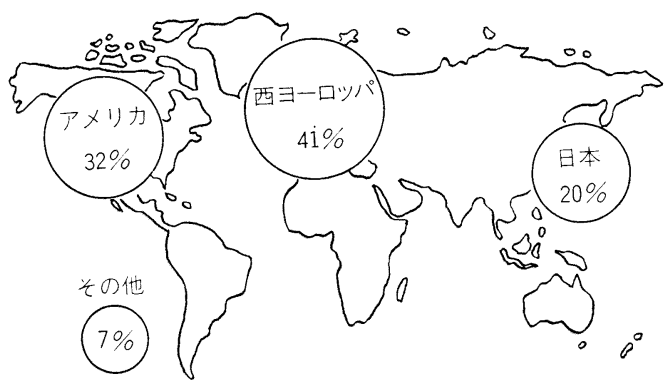

図 2 自由世界の地域別ニッケル消費

ると，アメリカではステンレス鋼及びその他合金鋼分野 で約 45\%，非鉄合金分野で約 35\%，めつき分野で約 15 $\%$, 残り約 $5 \%$ がその他の分野で消費されているのに対 し, 日本では約 $80 \%$ がステンレス鋼及びその他合金鋼分 野, 約 $5 \%$ が非鉄合金分野, 約 $10 \%$ がめつさ分野, 残 り $5 \%$ がその他の分野で消費されている. この消費構造 の違いがニッケルの形状別消費構造の違いとなつて現れ ている.すなわち，アメリカでの形状別消費内訳は電解 ニッケル及びブリケットなどの Class I ニッケルが約 70 \%, フェロニッケル及び酸化ニッケルなどのClass II = ッケルが約 30\% であるのに対し，日本ではClass I = ッケルが約 30\%, Class II ニッケルが約 70\% と反対の比 率になつている2). 図 1 及び図 2 は地域別ニッケル生産 量（銨石ベース）及び地域別ニッケル消費量を示したも のである. 自由世界のニッヶル生産の $42 \%$ を占めるカ ナダでの消費はわずか $2 \%$ で, 大半 $(93 \%)$ はアメリ カ, 日本及び西側ヨーロッパで消費され, 残り $5 \%$ がラ テンアメリカ及び極東で消費されている.

\section{2. 展望}

2.1 新規ニッケル源としてのマンガンノジュール

全海洋底に分布するマンガンノジュールは第 3 のニッ ケル源といわれている。このノジュールは海底堆積物の 最表層にあり，岩片，粘土，化石，魚骨等を核として同
心円状, 球果状を示し, 球状, ぶどら状等の形で賦存し ている.ノジュールの大きさは $2 \sim 7 \mathrm{~cm}$ 程度のものが 多く, 色は黒色ないし黒褐色を呈し, 比重は 2.1〜3.5, 水分率は $25 \sim 30 \%$ である.

このマンガンノジュールは $\mathrm{Mn}, \mathrm{Ni}, \mathrm{Co}, \mathrm{Cu}$ 等の金 属を含み, 水深 $4,000 \mathrm{~m} \sim 5,000 \mathrm{~m}$ の海洋底, 特に北太平 洋, 八ワイ南方海域北緯 $5^{\circ} \sim 15^{\circ}$, 西経 $115^{\circ} \sim 180^{\circ}$ の 南北約 $1,000 \mathrm{~km}$, 東西 $8,000 \mathrm{~km}$ のいわゆる Clarion Fracture Zone と呼ばれる東西に延びる帯状部に濃集し ているといわれている3).

マンガンノジュール中に含まれる有效金属成分として の $\mathrm{Mn}, \mathrm{Ni}, \mathrm{Co}, \mathrm{Cu}$ 等の含有比率は賦存地域により, また同一地域でも場所によつて変化が著しいといわれて いるが, “The Economic Value of Ocean Resources to the United States” (Dec. 1974) によれば Mn : 25 $\% \min , \mathrm{Ni}: 1.25 \%, \mathrm{Cu}: 1 \%$, Co: $0.22 \%$ がおのおの 含有されている。 また, マンガンノジュールの賦存埋蔵 量は 100 億 $\mathrm{t}$ から 5000 億 $\mathrm{t}$ といわれて和り，かりに各 金属の回収率を $27.5 \%$ とするとマンガンノジュールか ら $\mathrm{Mn}: 7$ 億 $\mathrm{t} \sim 340$ 億 $\mathrm{t}, \mathrm{Ni}: 3400$ 万 $\mathrm{t} \sim 17$ 億 $\mathrm{t}$, $\mathrm{Cu}: 2800$ 万 $\mathrm{t} \sim 14$ 億 $\mathrm{t}, \mathrm{Co}: 600$ 万 $\mathrm{t} \sim 3$ 億 $\mathrm{t}$ がお のおの回収されることとなる4).

この膨大な量の潜在資源が将来枯渴するであろう陸上 資源を補完する金属資源として世界的に注目され，各国 でその開発研究が進められているが，深海底採掘権をめ ぐる国際的な法律問題の解決にはまだ時間を要すると思 われ，また，技術面，コスト面から見ても解決すべき問 題が多々残されているので, 商業生産に入るのは 1990 年以降になるといわれている.

\section{$2 \cdot 2$ 自由世界のニッケル需給見通し}

\section{$2 \cdot 2 \cdot 1$ 自由世界のニッケル需要見通し}

1946 年から 1979 年にかけて自由世界のニッケル消費 の成長率は平均して年率 $5.6 \%$ であつたが，1970 年代だ けをとつてみると, 平均年率 $3.2 \%$ の伸びを示したにす ぎなかつた。すなわち 1970 年から 1974 年（オイルシ ョック）にかけての成長率は，平均年率 $6.5 \%$ ，また 1975 年から 1979 年にかけてのそれは約 $1 \%$ まで落ち込 んだのである.

この背景として，戦後 25 年間は西側諸国及び日本の 復興とステンレス鋼の, 特に日本における急成長により 特色づけられているのに対し, 最近 10 年間ではいくつ かのステンレス鋼市場が飽和点に近づたこと, 日本の 経済成長率の鈍化， ヨーロッパの低経済成長率及びO P $\mathrm{E} \mathrm{C}$ 諸国の相次ぐ石油価格值上げが，消費国にもたらし た計り知れぬほぼの経済的打撃などが特徽的である.

先進国の経済成長率が非常に低くなつていることから 判断し，今後のニッケル消費の成長率はかつてのような 高率に戻ることはないと思われるが，新規でかつ成長の 期待できる用途にニッケルが使用されていくであろらと 
の予測から年率平均 $4 \%$ 程度の伸び率は期待できるとい われている.

すなわち，多くの公害防止プロジェクトにはステンレ ス鋼，ニッケル合金が使用されて打り，この分野での二 ッケル需要は今後多年にわたり拡大し続けると考光られ る. また，電気自動車用のニッケル・覀鉛バッテリーも ニッケルにとつて将来性のある新規市場として期待され ているが，この種のバッテリーが本格的に生産されるよ らになるのは 1980 年代後半以降となろら。（ちなみに General Motors 社によれば，1985 年までに年間 100000 台の電気自動車が米国で生産されると考えられて扣り, その場合バッテリーでのニッケル消費量を $70 \mathrm{~kg}$ とする と年間 $7000 \mathrm{t}$ のニッケル消費増となる。)

このほか石炭液化などのエネルギ分野，さらには輸送 関係分野での潜在需要が顕在化してくるものと予想され る.

また，粗鋼生産とニッケル需要との間にはかなり密接 な相関関係があるといわれて抢り，1961 から1979 年ま での自由世界の粗鋼生産とニッケル需要との相関式を試 算した結果,

$Y=-150.143+1.42 \mathrm{X}$ (決定係数 : 93.19\%)

$Y:$ 自由世界のニッケル需要量 $(1000 \mathrm{t})$

$X$ : 自由世界の粗鋼生産量 $(100$ 万 $\mathrm{t})$

なる相関式が得られた。これに業界で一般にいわれてい る 1985 年及び 1990 年の自由世界の粗鋼生産予測数值 を代入すると自由世界のニッケル需要量は各々 66.5 万

$\mathrm{t}, 77.7$ 万 $\mathrm{t}$ となる・

なお，参考までに日本の粗鋼生産とニッケル需要との 間にもかなり密接な相関関係がある。 下記の式は 1961 年から 1979 年までの日本の粗鋼生産とニッケル需要と の相関式である.

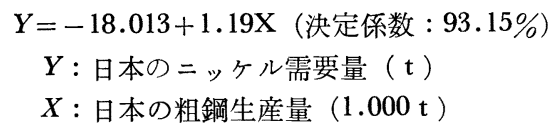

$2 \cdot 2 \cdot 2$ 自由世界のニッケル供給見通し

1979 年の自由世界生産能力は前述のと和り 74.2 万 $\mathrm{t}$ であるが，現在計画中のニッケルプロジェクトの新規生 産能力は, 既存ニッケル生産者の生産能力搪張計画を含 めると，1980 年から 1985 年の間に約 11 万 $\mathrm{t}$ ，また 1986 年から 1990 年の間にさらに約 11.8 万 $\mathrm{t}$ が見込まれて いる. 従つて現在計画中のニッケルプロジェクトが予定 通り進行し実現することを前提とすると，1985 年及び 1990 の自由世界の生産能力は打の打の, 85.2 万 $\mathrm{t}$ 及び 97 万 $\mathrm{t}$ となる.ただし, 現在計画中のプロジェクトの中 には実現性自体，あるいは実現の時期にかなり流動的な ものがあると思われること，並びに一般に発表されてい る生産能力は, 実際にフル稼動の経験をもた場合も多 多あることから，不確実な面があり，かつ，公害規制に より能力そのものがフルに使えぬ場合もあり得ることに
注意されたい.

自由世界の年間供給能力としては，このほかに共産圏 からの輸入があり，これを加味した 1985 年及び 1990 年の自由世界の最大ニッケル供給量は各々 91.7 万 $\mathrm{t}$ び 103.5 万 $\mathrm{t}$ となる。

図 3 は以上述べてきた自由世界の需給関係をグラフに まとめたものである. 長期予測の難しい変化の速い時代 であることを承知で行つた我々の一つの試算であるが, この試算が正しいとすれば，このグラフに示されるよう に, 突然のかつ大量のニッケル需要の増大, あるいは重 要生産拠点に灾けるストライキ，その他によつて長期的 に生牶が阻害される事態が起こらぬ限り，今後 10 年間 は基本的にニッケルが供給不足になることは考えられな い.

\section{$2 \cdot 3$ ニッケルの生産者価格 (P. P.) の見通し}

表 6 は INCO 社の溶解用電解ニッケルの 1966 年以 降の P. P. の推移と, 1966 年の P. P. を年率 $11 \%$ で 上昇させたトレンド数值との比較である。この表から 1966 年から 1976 年までの 11 年間に INCO はニッケル 価格を年率平均 $11 \%$ のペースで值上げしてきたことが わかる. INCO 社のこの安定した值上げがその後ニッケ ル産業に新規生産者, 例えば Amax (アメリカ), Queensland Nickel (オーストラリア), Marinduque (フィ リピン）などのあいつぐ参入を招いたと考えられる.さ らにこれら新規参入者による大幅な生産能力の増加が世 界の需給バランスを大幅に崩すことになり，1977 年には 主要ニッケル生産者が P. P. 発表を撤回するなど,いわ ゆる価格戦争の時代に突入した。この時代にはニッケル 価格は \$1.70/lb (\$3.75/kg) と 1977 年の P. P. 発表

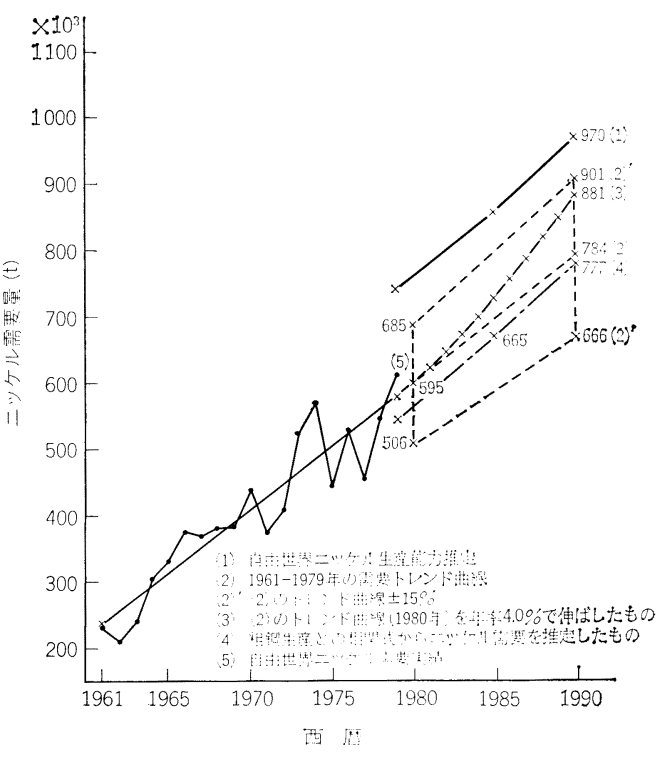

脳3自由世界のニッケル需給見通し 
㤗 6 ニッケルの生産者価格(P.P.)の動向

\begin{tabular}{|c|c|c|}
\hline & INCO P.P. & 年率 $11 \%$ トレンド \\
\hline 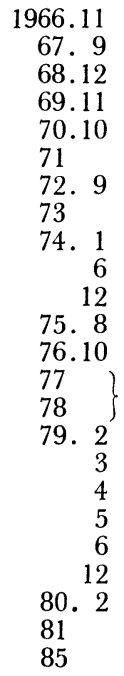 & $\begin{array}{c}\not \subset 85.25 / \mathrm{lb} \\
94.00 \\
103 \\
128 \\
133 \\
\\
153 \\
\\
162 . \\
185 \\
201 \\
220 \\
241 \\
\mathrm{P} . \mathrm{P} . \text { 中断 } \\
205 \\
225 \\
250 \\
285 \\
300 \\
320 \\
345\end{array}$ & $\begin{array}{c}(\not 85.25 / \mathrm{lb}) \\
94.63 \\
105.04 \\
116.60 \\
129.42 \\
143.65 \\
159.45 \\
176.99\end{array}$ \\
\hline
\end{tabular}

中断直前の P. P. から 30\% も下落し, ほとんどの二ッ ケル生産者の採算は赤字に転落した. しかしながら， 1978 年から 1979 年にかけ, INCO 社最大の生産基地で ある Copper Cliff (オンタリオ州) で約 6 ヶ月に及ぶ労 働争議が発生し，このために自由世界の需給はバランス へと向かい，1979 年 2 月に INCO 社を手始めに主要生 産者は一斉に P. P. 発表を再開した.そしてわずか 1 年 後の 1980 年 2 月までに $\$ 3.45 / \mathrm{lb}(\$ 7.61 / \mathrm{kg})$ とニッ ケル P. P. は約 1.7 倍に上昇した.

さて, 今後ニッケル P. P. はどのように推移していく であろらか?

価格に影響を与える大きな要因は，生産コストと需給 バランスである.

今後 10 年間の需給バランスについては, 前述した通 り基本的な供給不足は考觉られず，さりとて生産過剩の 事態にも 1977 年及び 1978 年の苦汁を経験している各 生産者は減産により対処すると考えられるため，需給は ほどほどにバランスを保つて推移していくものと思われ る.

この前提に立てば，今後の P. P. 動向を予測する際の
表 7 ラテライト鉱からフェロニッケルを生産する 企業の推定コスト

(単位: US $₫$ per lb)

\begin{tabular}{|c|c|c|c|c|c|}
\hline & 1979 & & 1980 & & 1985 \\
\hline $\begin{array}{l}\text { エネルギコスト } \\
\text { 労働コスト } \\
\text { 借入金の利息 } \\
\text { 减価償却 } \\
\text { 乙の他コスト }\end{array}$ & $\begin{array}{l}99 \\
37 \\
24 \\
17 \\
61\end{array}$ & $\begin{array}{l}65 \% \text { 上昇 } \\
10 \% \text { 上昇 } \\
\text { - } \\
10 \% \text { 上昇 }\end{array}$ & $\begin{array}{r}163 \\
41 \\
24 \\
17 \\
67\end{array}$ & $\begin{array}{c}\text { 年率15\%上昇 } \\
\text { 年率10\%上昇 } \\
- \\
\text { 年率10\%上昇 }\end{array}$ & $\begin{array}{r}326 \\
73 \\
24 \\
17 \\
108\end{array}$ \\
\hline 全コスト & 238 & & 312 & & 548 \\
\hline $\begin{array}{c}\text { P.P.平均 }(\phi / \mathrm{lb}) \\
\text { 原油の平均価格 } \\
(\$ / \text { バレル) }\end{array}$ & $\begin{array}{l}271 \\
18 . \\
20\end{array}$ & $65 \%$ 上昇 & $\begin{array}{c}339 \\
\\
30 \\
(\mathrm{E})\end{array}$ & 年率 $15 \%$ 上昇 & $\begin{array}{l}619 \\
(\mathrm{E}) \\
60 \\
(\mathrm{E})\end{array}$ \\
\hline
\end{tabular}

唯一，かつ最大の要因は生産コストになると思われる.

表 7 は酸化鉱からフェロニッケルを生産しているある 会社の生産コストの推定である.この表からわかるよう に酸化鉱からのニッケル生産には, 大量のエネルギが必 要とされる. 一方, 相対的に安価な代替エネルギが開発 されぬ限り, 今後ともエネルギコストは高率で上昇して いくであろう. 一般的に原油価格が \$1/バレル（0.159 $\mathrm{k} l)$ 上昇すると酸化鉱からの二ッケル生産コストは $₫ 5$ 〜 6 6/1b ( $\notin 11 \sim \not 13 / \mathrm{kg})$ 上昇するといわれている. か りに原油価格が今後年率 $15 \%$ で上昇していくとする と，1985 年には酸化鉣からの二ッケル生産コストは\$ $5.48 / \mathrm{lb}(\$ 12.08 / \mathrm{kg})$ となり，乙れに生産者の最低の利 益として約 10\%を加えると, 1966 年をべースとした二 ッケル P.P.の年率 11\% トレンドを延ばした 1985 年 の価格 $\$ 6.19 / \mathrm{lb}(13.65 / \mathrm{kg})$ とほぼ一致する.

もちろん実際の P. P. 引上げの時期については市況, 生産者間の競争などの要因がからむが，すう勢として， 今後も P.P.はュストアップを吸収する方向で引き上げ られていくものと予想される.

\section{交献}

1) Nickel Topics $(31 /(1978) 4,33 /(1980) 1$ [INCO 社]

2) Nickel Data (三井物産) (55年 7 月)

3 ) マンガン団塊開発に関する経済性の研究 (マンガンノジュール研究会) (53年 3 月)

4) Nickel (U. S. Bureau of Mines) (May 1979) 